\title{
Decentralized Natural Resource Management: A Review of Devolution of Property Rights and People's Participation
}

\author{
Pratyusna Patnaik \\ Assistant Professor, Centre for Panchayati Raj (CPR), \\ National Institute of Rural Development \& Panchayati Raj (NIRDPR), Hyderabad, Telangana, India \\ E-mail: pratyusna.nird@gov.in
}

\begin{abstract}
Recent decades have witnessed an increased attention towards emergence of decentralized strategies in natural resource management, as a solution to problems of overexploitation and degradation of natural resources. However, it is important to note that central to the processes of decentralisation in natural resource management is that of the concept of property rights. Successful decentralisation in natural resource management requires effective institutions be in place at local level with clearly defined property rights. In this context, the present paper analyses the process of changing property rights in decentralized natural resources management. It explores different forms of property rights and answers the question as to which type of property rights must be devolved to the user groups, if decentralized natural resource management is to be effective and sustainable.

Keywords: Natural Resource Management, Devolution, Property Rights, Participation
\end{abstract}

\section{INTRODUCTION}

Decentralisation has emerged as an efficient policy strategy in many of the developing countries in recent decades to achieve better outcomes in development goals, provisioning of public services and in use, management and conservation of environmental resources. Before proceeding further in discussing the processes of decentralisation of natural resource use and management, it is apt to distinguish the process from that of political or democratic decentralisation. While democratic decentralisation is meant as a process of transfer of authority and responsibility from national governments to that of democratically elected local governments to manage local affairs, decentralized natural resource management should be understood as a policy strategy of transferring responsibilities and authorities over use and management of natural resources from state bureaucracy to non-governmental bodies, particularly to user-groups (see, Knox and Meinzen-Dick, 2001). Thus, whereas the former necessarily involves democratic components such as representation, responsiveness, accountability and participation, the later is more concerned with conservation sustainable use and management of natural resources, where the users get assured rights to access the resource.

Much of the scholarships on the process of decentralisation in the context of use and management of natural resources, tend to over emphasize the superiority of decentralized solutions as against centralized one based on the grounds of efficiency, equity and environmental sustainability, without paying sufficient attention to the nature of property rights that are devolved in the process of decentralisation of natural resource use and management. The arguments of decentralized natural resource use and management is mostly regarded as a direct response to the limited effectiveness of the central state in managing natural resources, especially at the local level. Government agencies in many countries have faced difficulties in monitoring the use of extensive forest land, constantly moving irrigation flows and/or mobile fishery resources. In a situation where the state cannot implement the rules concerning governing of these resources, the rules become redundant and the resources get degraded. Juxtaposed to the repeated emphasis of the inherent inadequacies of state run management of natural resources, several studies have also pointed out the benefits of local resource use and management based on grounds of superior indigenous knowledge, close proximity with resource base, and continued dependence on resource base for livelihood purposes. It is often highlighted that these factors generate incentives for the local communities to use and manage resources on a sustainable basis (Baland and Platteau, 1996; Ostrom, 1990).

Lack of attention to property rights in the context of decentralized resource use and management often results in a poor understanding of the relationship between property rights and political authority and more importantly which forms of property rights should be devolved for successful decentralisation. It is important to note, therefore, that central to the processes of decentralisation in natural resource management is that of the concept of property rights, since successful decentralisation requires effective institutions be in place at local level with clearly defined property rights. The act of decentralisation of natural resources results in emergence of new actors, who can make decisions about the disposition of these resources. As authority and responsibilities concerning natural resources are devolved to local levels, locally situated actors get different rights of use, access and making decision over the resources. Decentralisation of natural resources, therefore, necessarily involves reforms in existing property right arrangements, and generates a different structure of rights over the resource. Property rights, however, should not be limited only to ownership over the resource, and thought of 
as that of private or state ownership. Property rights in the context of natural resources is a dynamic concept, which involves layers of rights over the resource, such as withdrawal, management, exclusion and alienation. Most importantly different types of property rights generate varying consequences for use and management of the resource.

In the context of the above background, the main objective of the present paper is to critically review and analyse the process of changing property rights in decentralized natural resources management. It also attempts to explore the recent reforms in the property right arrangements in the whole process of decentralized natural resource management. The paper is divided into five sections. Following the introduction, the second section engages itself with a conceptual understanding of decentralisation and property rights in the context of natural resource management. The fourth section investigates the question of changing property rights in the context of Participatory Irrigation Management, and the fifth section puts forth the summary and conclusion of the paper.

\section{DECENTRALISED NATURAL RESOURCE MANAGEMENTAND PROPERTY RIGHTS: CONCEPTUAL UNDERSTANDINGS}

We may broadly identify two main phases of public policy in the post-colonial development discourse (Siva rama Krishnan and Agrawal, 1998). In this phase central state was viewed as playing a pivotal role in planning and implementing development policies and programmes, especially in developing countries, where the state was trying to emulate the growth patterns of western capitalist economies. The second phase of policy discourse in the context of development started in the late 1970s, as failures of the central state in delivering development become more prominent. While on the one hand, it emphasizes, privatization, liberalization, export promotion, openness to international market, etc., on the other hand, recognizing the limits of these policy innovations to address issues of equity, it advocated frameworks of decentralization and people's participation (Agrawal and Ostrom, 2001).The new development paradigm that has emerged since mid-1980s, as a modification to the second phase of post-colonial development debate, therefore, place a high value to community and its institutions in delivering development, and managing local resource base. What has emerged in the process is that of 'decentralisation', which tries to fulfill the institutional void at the local level to ensure participation, local service delivery and better developmental outcomes.

\section{A. Conceptualizing Decentralization}

At a general level, decentralisation aims to achieve one of the central aspirations of just political governance, i.e. democratisation, or the desire that humans should have a say in their own affairs. A political system, that involves decentralisation of power functions in a way that the local affairs of the people are managed by themselves and with their active participation. But decentralisation is also synonymous with redistribution of power and resources, which involves first, a division of the state's territories into smaller sub-units and then providing them with political and administrative institutions.

Decentralization, therefore, can be seen as a strategy of governance to facilitate transfer of power closer to people, who are most affected by the exercise of power. Capturing the essence of the idea of decentralisation, Blair (2000: 21) writes, 'decentralisation can be defined as meaningful authority devolved to local units of governance that are accessible and accountable to the local citizenry, who enjoy full political rights and liberty'. It is a policy reform, in which central government agency transfers rights and responsibilities to institutions at local levels, to which people have more access and control.

The process of democratic decentralisation, when put into practice, manifests itself in several dimensions. On occasion, it entails the transfer of power and responsibility from a higher level to a lower level of government, necessarily involving a hierarchical division, while at other times decentralisation takes the form of simple horizontal division of functions of the government.Analysing the transfer of power and responsibility in greater detail, Rondinelli, et al., (1984: 13-32) identify four dimensions of decentralisation, namely a) deconcentration, b) delegation, c) devolution and d) privatisation.

Deconcentration is the handing over of some amount of administrative authority or responsibility to the lower levels within central government, ministries and agencies. Delegation refers to a situation in which the central government transfers responsibility for decision making and administration of public functions to local governments or semiautonomous organizations that are not wholly controlled by the central government, but are ultimately accountable for it. Devolution, as a more extensive form of decentralisation, refers to a situation in which the central government transfers authority for decision-making, finance, and management to quasi-autonomous units of local government.

Devolution usually transfers responsibilities for services to municipalities or local governments that elect their own officials, raise their own revenue, and have independent authority to make investment decisions. Privatization refers to the passing of all responsibilities for functions to nongovernmental organizations or private enterprises independent of government.

\section{B. Property Rights and Decentralization}

In the context of use and management of natural resources, decentralisation may be understood as a process, through which central government transfers rights of decision making over resources, such as water, forests, grazing land, 
fisheries, to actors and their institutions at local levels in a politico-administrative and territorial hierarchy. In this process, the means, through which new actors and institutions come forward to gain new powers of decision making over resources, are different combinations of property rights (Agrawal and Ostrom, 2001).

In order to have a proper understanding of property rights, we need to distinguish property from another related concept, i.e. resource. 'Resources' are mere physical phenomena, which are put to use to derive benefits out of it, and may be either natural or man-made. Natural resources are often defined as 'those components of an ecosystem which provides goods and services useful to mankind' (Gibbs and Bromley, 1991: 22). 'Property', on the other hand, refers to an institutional arrangement in the resource or a special kind of human intervention, which defines individuals' relationship with resources. The institution of property is the 'result of a secure claim to a resource or the services that resources provide' (Gibbs and Bromley, 1991: 24). Thus, property is not the resource itself, rather a social relation that defines the rights of the property holder to the resource in relation to others who have a corresponding duty to respect that right.

Successful decentralisation of resource management results in the new actors who can make decisions about the use and management of these resources. As government formulates new policies concerning decentralized management of natural resources, it allows actors at lower levels to have a greater voice in deciding the fate of these locally situated resources. Such transfer of rights over the resources generates new forms of property rights over the resource involving new actors. It is important to understand in this context, which types of property rights are devolved to local user groups in the process of decentralised natural resource management. We, therefore, need to understand various types of property rights that exists in the context of use and management of natural resources. Schalger and Ostrom (1992) identify five different types of property rights, i.e. access, withdrawal, management, exclusion and alienation; that are most relevant for the use and management of natural resources.

Access right corresponds to right to access a resource base and enjoy non-subtractive benefits from it. Withdrawal is the right to obtain resource units or products from a resource system, for example, collecting forest produces from a forest area, diverting water to one's own field from a water source or catching fish from a pond. Management is the right to regulate internal use patterns and transform resources by making improvements, e.g. planting saplings, thinning trees, etc. The right to exclusion determines who will have access and withdrawal rights in the sense who will be permitted to have a share from the resource and how that right is transferred. Alienation is the exclusive right of selling or leasing access, withdrawal, management and exclusion rights. Private property is frequently defined as having a well-defined right structure, with full rights of alienation, which in turn includes the other four types of property rights.

\section{DECENTRALISATION AND PROPERTY RIGHTS IN PARTICIPATORY NATURAL RESOURCE MANAGEMENT}

The outcomes of decentralisation policies, however, do not necessarily depend upon mere formulation of devolutionary policies and transfer of management responsibilities to the farmers at the local levels. Instead, the outcomes of such decentralized natural resource management depends more upon factors like collective action, institutional arrangements and existing property rights arrangements. The following paragraphs describe these concepts and processes and highlight their crucial role for success of decentralized natural resource management.

\section{A. Collective Action and Institutional Arrangements}

For the success of decentralized natural resources management, it is highly essential that strong and robust institutional arrangements are in place, which can initiate and sustain collective action for sustainable and efficient resource management. Grassroots institutions hold the potency to contribute to better system performance because of their advantages over a public agency, on the one hand, and over uncoordinated activity by individuals, on the other. One of the important functions of institutional arrangements in natural resource management is that of monitoring the distribution of resources and ensuring equitable distribution of resource units. In this context, institutions will contribute towards improvement of system maintenance, since they have a greater stake in the systems, and therefore, are more likely to monitor the condition of resource.

However, all these will be possible only if decentralized resource management can generate and sustain collective action among farmers at the local level. Since decentralized resource management is based on the assumption that users will take on the roles formerly assigned to state, it requires some form of collective action to coordinate individuals' activities, to develop rules for resource use, to monitor compliances with the rules and sanction violators, and to mobilize the necessary capital, labour and the material resources. Crucial for devolutionary policies like in resource management, therefore, is that under what conditions such collective action and institutional arrangements will emerge and be strong enough for sustainable management of natural resources.

\section{B. Devolution of Property Rights}

Decentralised natural resource management to a great extent depends upon transfer of property rights over the resource base from state bureaucracy to the farmers at the local level. It is, however, important to understand what types of rights are devolved to people in the process of decentralized 
resource management, which holds the pivotal position for its success or failure.

We may analyze devolution of property rights in decentralized natural resource management with the help of theoretical framework provide by Schlager and Ostrom (1992), which distinguish between different types of resources users, such as: owners, proprietors, (authorized) claimants and (authorized) users, who have different types of property rights at their disposal.

Those having only the access and withdrawal right, i.e. right to enter into and harvest some form of products from the resource base are called 'authorized users'. Claimants besides possessing the right to access and withdrawal, also hold a collective choice right of management. The right to manage in the context of natural resources may include decisions concerning the construction and maintenance of the resources, the authority to devise limits on harvesting of the resource, and the ability to enforce the devised limits
(Tang, 1992). Users having the management rights over a resource also are also able to make their own rules concerning how to limit the timing, location and technology of use that fit to local circumstances (Ostrom, 1990).

Proprietors hold all the rights similar to that of claimants with the addition of exclusion rights, i.e. the right to determine who may harvest from a resource.

Most of the attempts of devolution of natural resources for creation of common property arrangements turns users into proprietors, who have all the four rights mentioned above apart from the alienation right. In contrast to proprietors, owners possess the right of alienation, i.e. the right to transfer a good in way s/he wishes, but without harming the physical attributes of the resource or uses of other owners, and also the right held by the proprietors.

The following table pits different resource users in the back drop of different kinds of property rights.

TABle 1: Multiple Property Rights And Multiple Resource Users

\begin{tabular}{|l|c|c|c|c|}
\hline \multirow{2}{*}{ Types of Property Rights } & \multicolumn{5}{|c|}{ Types of Resource Users } \\
\cline { 2 - 5 } & Owners & Proprietors & Authorized Claimants & Authorized Users \\
\hline Access & $\checkmark$ & $\checkmark$ & $\checkmark$ & $\checkmark$ \\
\hline Withdrawal & $\checkmark$ & $\checkmark$ & $\checkmark$ & $\checkmark$ \\
\hline Management & $\checkmark$ & $\checkmark$ & $\checkmark$ & \\
\hline Exclusion & $\checkmark$ & $\checkmark$ & & \multicolumn{3}{|c|}{ Source: Schalger and Ostrom (1992: 252) } \\
\hline Alienation & $\checkmark$ & \multicolumn{5}{|c|}{} \\
\hline
\end{tabular}

The analysis of multiple property rights and multiple positions of resources users extend certain implications for decentralized management of natural resources. Most of the earlier attempts of decentralisation of natural resources extended only the access and withdrawal right, making the resource dependent only authorized users of the resource. Only on occasions they were made claimant with little managerial rights.

All the other significant property rights continue to be held by the government official. Transfer of such limited property rights could not generate sufficient incentive structure for resource users for sustainable use and management of natural resources. Such attempts of decentralisation remained limited to de-concentration and delegation, without involving sufficient devolution of power, authority and responsibility to make decisions over the use and management of natural resources.

The absence of effective devolution of managerial and exclusion rights results in domination of the resource users by distant power holders, who may take away the important benefits out of the resource. An effective decentralisation reform therefore, should involve successful devolution of decision making, managerial and exclusion rights to the resource users.

\section{CONCLUSION}

We may therefore conclude that attempts to decentralisation of natural resources, ultimately depends upon the type of property rights devolved to resource users. Since the property rights structures generate incentives or disincentives for sustainable management of a resource base, it is essential to pay proper attention to devolution of property rights to resource users at the local level. The attempts to decentralisation of forest and water resources in India, therefore, requires full devolution of all forms of property rights to the farmers, which will then generate positive incentives among farmers to establish robust institutional arrangements at field level and participate in collective action for sustainable management of water resources. Piece meal approaches to devolution, by way of transferring only limited rights to farmers may not generate sustainable resource management regimes in the long run. The success of participatory forest and water resource management, therefore, lies in full devolution of different forms of property rights to the farmers at the local level. Sufficient attention should also be paid for establishment of robust institutions, which can utilize these property rights for ensuring collective action for decentralized management of natural resources. 


\section{REFERENCES}

[1] Agrawal, A. \& E. Ostrom (2001). Collective Action, Property Rights, and Decentralization in Resource Use in India and Nepal, Politics and Society, 29(4), $485-514$.

[2] Baland, J. M. and J. P. Platteau (1996). Halting Degradation of Natural Resources: Is There a Role for Rural Communities? Oxford: Oxford University Press.

[3] Gibbs, C. J. N. \& Daniel W. Bromley. (1991). 'Institutional Arrangements for Management of Rural Resources: Common Property Regimes'. In FikretBerkes (Ed.) Common Property Resources: Ecology and Community-based Sustainable Development. Dehra Dun: International Books Distributors.

[4] Knox, A. \& R. Meinzen-Dick. (2001). Collective Action, Property Rights, and Devolution of Natural Resource Management: Exchange of Knowledge and Implications for Policy, Capri Working Paper, 11.
Washington, D.C: International Food Processing Research Institute (IFPRI).

[5] Ostrom, E. (1990).Governing the Commons: Evolution of Institutions for Collective Action. New York: Cambridge University Press.

[6] Rondinelli, D. A., J. R. Nellis \& G. S. Cheema. (1984). 'Decentralisation in Developing Countries: A Review of Recent Experiences', World Bank Staff Working Papers No. 581. Washington, D. C: The World Bank.

[7] Schlager, E. \& E. Ostrom (1992). Property-rights Regimes and Natural Resources: A Conceptual Analysis. Land Economics, 68(3), 249-62.

[8] Sivaramakrishnan, K. \& A. Agrawal. (1998). 'Regional Modernities in Stories and Practices of Development'. YCIAS Working Paper 1. New Heaven: Yale University.

[9] Tang, S. Y. (1992). Institutions and Collective Action: The Case of Irrigation Systems. San Francisco: ICS Press. 